\title{
Pengaruh Corporate Governance Dan Sharia Compliance Terhadap Nilai Perusahaan Dalam Penawaran Saham Perdana (Initial public Offering) Di Bursa Efek Indonesia
}

\section{Deni Hidayat}

Program Pascasarjana, Magister Ekonomi Syariah, Sekolah Tinggi Ekonomi

Islam Tazkia

Email:d2ntea@gmail.com

\begin{abstract}
The purpose of this study is to examine the effect of corporate governance and sharia compliance on firm value at the time of initial public offering at Indonesia Stock Exchange. To measure the quality of corporate governance an index is developed based on regulations issued by Financial Service Authority $(\mathrm{OJK})$ and Indonesia Stock. Exchange as guidelines. The data used in this study are obtained from prospectus of companies that conducted initial public offering at Indonesia Stock Exchange within period of 2013 to 2016. Using purposive sampling method, 56 companies obtained to be used as research sample and then multiple linear regression is used to test the bypothesis. The result show that there is a positive and significant effect of corporate governance on firm value, indicating that companies with better corporate governance have higher valuation at the time of IPO, while the sharia compliance is not associated with firm value.
\end{abstract}

Keyword: Corporate Governance, Firm Value, Sharia Compliance

\begin{abstract}
Abstrak
Penelitian ini bertujuan untuk menguji pengaruh corporate governance dan pemenuban ketentuan syariah (sharia compliance) terhadap nilai perusabaan saat melakukan penawaran sabam perdana. Untuk mengukur kualitas corporate governance dibuat sebuah indeks yang mengacu kepada ketentuan-ketentuan yang dikeluarkan Otoritas Jasa Keuangan dan Bursa efek Indonesia. Data yang digunakan dalam penelitian ini diperoleh dari data prospektus perusahaan yang melakukan penawaran saham perdana di Bursa Efek. Indonesia dalam periode 2013 sampai dengan 2016, dengan menggunakan teknik purposive sampling diperoleh 56 perusabaan yang dapat dijadikan sampel penelitian. Model regresi linear berganda digunakan dalam penelitian ini untuk menguji bipotesis penelitian. Hasil pengujian menunjukan adanya pengarub positif yang signifikan dari corporate governance terhadap nilai perusahaan, dimana perusabaan dengan corporate governance yang baik mendapatkan nilai perusahaan yang lebih tinggi. Sementara untuk pemenuhan ketentuan syariah (sharia compliance) tidak berpengaruh terhadap nilai perusahaan.
\end{abstract}

Kata Kunci: Corporate Governance, Nilai Perusahaan, Syariah Compliance

Al Falah: Journal of Islamic Economics, Vol. 3, No. 2, 2018

STAIN Curup|E-ISSN: 2548-3102, P-ISSN: 2548-2343

Available online: http://journal.staincurup.ac.id/index.php/alfalah 


\section{PENDAHULUAN}

Untuk membiayai pengembangan bisnisnya, perusahaan mempunyai beberapa opsi sumber pendanaan antara lain penambahan modal sendiri, penerbitan obligasi, pinjaman bank dan dari pasar modal. Bagi perusahaan yang bergerak dibidang bisnis syariah ataupun pelaku usaha yang ingin bisnisnya berjalan sesuai syariah pinjaman dana yang mengandung unsur ribawi harus dihindari, salah satu alternatif yang memungkinkan adalah mengakses dana masyarakat dari pasar modal baik melalui mekanisme penawaran saham perdana (Initial Public Offering) ataupun penerbitan Sukuk.

Untuk mengakomodasi investor yang ingin bertransaksi sesuai prinsipprinsip syariah, pada tahun 2000 Bursa Efek Jakarta bekerjasama dengan Dana Reksa Investment Management meluncurkan Jakarta Islamic Index (JII) yang memilih 30 saham emiten yang kegiatan usahanya memenuhi kriteria syariah. Adanya JII ini menjadi acuan bagi investor terkait kinerja saham-saham yang syariah compliant dan menjadi awal berkembangnya pasar modal syariah. Pada dasarnya Pasar Modal Syariah sendiri tidak memiliki perbedaan dengan pasar modal konvensional kecuali pada pasar modal syariah mekanisme transaksi dan produk yang diperjual belikan harus mengacu kepada prinsip-prinsip syariah, terbebas dari unsur riba, gharar dan maisir. Mekanisme syariah di pasar modal diatur berdasarkan fatwa Dewan Syariah Nasional Majelis Ulama Indonesia (DSN-MUI) Nomor 40/DSN-MUI/X/2003 Tentang Pasar Modal dan Pedoman Umum Penerapan Prinsip Syariah di Bidang Pasar Modal. Berdasarkan data dari Bursa Efek Indonesia sampai dengan akhir kwartal pertama 2017, terdapat 543 perusahaan yang telah mencatatkan dan memperdagangkan sahamnya di Bursa Efek Indonesia dengan 331 (61\%) diantaranya termasuk kedalam Daftar Efek Syariah. Dengan adanya Daftar Efek Syariah ini memberikan semakin banyak pilihan kepada investor yang ingin berinvestasi sesuai syariah di pasar modal.

Initial public offering atau penawaran saham perdana kepada publik merupakan gerbang bagi sebuah perusahaan tertutup untuk melangkah menjadi sebuah perusahaan terbuka dan mencatatkan sahamnya di bursa efek untuk diperdagangkan. Dengan melakukan penawaran saham perdana sebuah perusahaan akan mempunyai akses untuk mendapatkan dana dari masyarakat untuk membiayai ekspansi perusahaannya namun sebagai konsekuensi dari penggunaan dana masyarakat, perusahaan terbuka dituntut untuk mengelola dan menggunakan dana masyarakat tersebut dengan baik, transparan dan akuntabel, sehingga penerapan Good Corporate Governance menjadi sebuah kewajiban bagi perusahaan yang telah go public. 
Perusahaan yang telah menerapkan prinsip-prinsip good corporate governance dan didukung regulasi yang tepat dapat mencegah segala bentuk kecurangan yang dapat merugikan stakeholders. Selain itu manajemen mempunyai pedoman yang baik dalam pengambilan keputusan, sehingga pengelolaan perusahaan menjadi lebih efisien dan terhindar dari konflik kepentingan diantara stakeholder. Hal ini menyebabkan perusahaan yang telah menerapkan good corporate governance dengan baik lebih dipercaya oleh kreditor dan investor sedangkan perusahaan yang mempunyai reputasi kurang baik dalam hal corporate governance akan dijauhi investor ${ }^{1}$. Bukti empiris dari Lebanese Transparency Association ${ }^{2}$ menunjukan bahwa $84 \%$ dari investor institusi global bersedia membayar harga premium untuk saham sebuah perusahaan yang menerapkan tata kelola yang baik dibanding perusahaan dengan tata kelola yang kurang baik dengan catatan keuangan yang sebanding.

Dalam membuat keputusan investasi, setiap investor memerlukan informasi yang cukup sehingga dapat mengukur tingkat resiko dan prospek dari investasi tersebut. Perusahaan yang akan melakukan IPO harus menyediakan informasi yang lengkap meliputi aspek hukum, keuangan, prospek bisnis, resiko bisnis termasuk corporate governance dan informasi lain yang dianggap penting kedalam sebuah prospektus. Berdasarkan informasi dalam prospektus tersebut investor dapat menganalisa perusahaan tersebut termasuk terkait pemenuhan kriteria syariah, untuk sebagian investor informasi syariah compliance ini penting dan berpengaruh dalam mengambil keputusan investasi ${ }^{3}$. Seluruh informasi yang disediakan perusahaan merupakan sinyal yang dapat membentuk persepsi investor terkait kualitas dan nilai perusahaan tersebut sehingga mempengaruhi investor dalam menentukan jumlah permintaan saham dan harga saham yang dapat mereka diterima. Ketersediaan informasi yang lengkap diharapkan dapat memaksimalkan nilai perusahaan saat melakukan IPO.

Pada penelitian yang dilakukan oleh Hartzel, Kallberg dan Liu (2008) ${ }^{4}$ menemukan bahwa perusahaan dengan corporate governance yang kuat mendapat

1 Windah Gabriela C dan Andono Fidelis A (2013), Pengaruh Penerapan Corporate Governance Terhadap Kinerja Keuangan Perusahaan hasil Survei The Indonesian Institute Perception Governance (IICG) Periode 2008-2011, Jurnal Ilmiah Mahasiswa Universitas Surabaya Vol 2 No.1 Association

2 Meouchi Badri El. 2007. The Benefit of Corporate Governance, Lebanese Transparency

${ }^{3}$ Alqahtani F and Boulanouar Z. 2017. Sharia compliance status \& investor demand for IPOs: Evidence from Saudi Arabia. Pacific-Basin Finance Journal Volume 46, Part B, 258-268

${ }^{4}$ Hartzell Jay C, Kallberg Jarl G and Liu Crocker H. 2008. The Role of Corporate Governance in Initial Public Offerings: Evidence from Real Estate Investment Trust. The Journal of Law and Economics Vol.51 
valuasi yang lebih tinggi pada saat melakukan IPO. Penelitian Ozcelik (2014) ${ }^{5}$ menunjukan kepemilikan saham oleh existing shareholder merupakan sinyal positif atas kualitas perusahaan dan berpengaruh positif terhadap nilai IPO perusahaan. Cheung et all (2014) ${ }^{6}$ mengembangkan corporate governance index (CGI) berdasarkan prinsip-prinsip yang ditetapkan OECD, hasilnya menunjukan adanya hubungan positif antara kualitas corporate governance dengan nilai perusahaan. Hasil penelitian-penelitian tersebut diatas sejalan dengan beberapa penelitian sebelumnya yang menemukan adanya pengaruh positif corporate governance terhadap nilai perusahaan sebagaimana dalam penelitian Gomper, Ishii dan Metric (2003) ${ }^{7}$ dan penelitian Amman, Oesch dan Schmid (2009) ${ }^{8}$.

Hasil berbeda ditemukan dalam beberapa penelitian lain, Bhalla, Bhatia dan Kaushal (2012) ${ }^{9}$ yang tidak menemukan pengaruh corporate governance terhadap IPO Underpricing di India, sementara Haat et al (2008) ${ }^{10}$ menyimpulkan pengaruh corporate governance dalam hal ini transparansi tidak mempunyai kontribusi signifikan terhadap nilai perusahaan, namun dalam penelitian yang sama ditemukan bahwa corporate governance mempengaruhi nilai perusahaan melalui mekanisme debt monitoring dan kepemilikan asing.

Berbeda dengan penelitian terkait hubungan corporate governance dan nilai perusahaan yang telah banyak dilakukan, penelitian terkait shariah compliance dengan nilai perusahaan masih sangat terbatas. Bakar and Uzaki (2013) ${ }^{11}$ meneliti IPO underpricing untuk perusahaan shariah-compliant dan non-shariah compliant yang tercatat di bursa efek Malayasia, hasil penelitian menemukan bahwa perusahaan yang shariah compliant mengalami tingkat underpricing sedikit lebih tinggi dibanding perusahaan non-shariah compliant. Penelitian lain terkait

${ }^{5}$ Ozcelik Zeynep. 2014. The Impact of Ownership Retention on IPO Firm Value. British Journal of Economics, Finance and Management Sciences Volume 9, 133-148

${ }^{6}$ Cheung Y.L, Connelly J.T, Estanislao J, Limpaphayom, Lu T, Utama. 2014. Corporate Governance and Firm Valuation in Asian Emerging Markets, Springer-Verlag Berlin Heidelberg

7 Gompers, P., J. Ishii, and A. Metrick. 2003. Corporate Governance and Equity Prices. Quarterly Journal of Economics, 118, 107-155

8 Amman Manuel, Oesch David and Schmid Markus. 2009. Corporate Governance and Firm Value: International Evidence, Swis Institute and Banking Finance, University of St Gallen, Working Paper

9 Bhalla Lalit, Bhatia Akshay, Kaushal Vijay. 2012. Corporate Governance and IPO Underpricing, Jounal of Commerce and Accounting Research Vol.1 Issue 3

10 Haat, Rahman, Mahenthiran. 2008. Corporate Governance, Transparency and Performance of Malaysian Companies. Managerial Auditing Journal Volume. 23 No.8, 744-778

${ }^{11}$ Bakar, N. A and Uzaki, K. 2013. Initial Public Offerings (IPOs): An Empirical Study of Initial Public Offerings Underpricing For Shariah-compliant Companies: The Case of Malaysian Market. International Journal of Economics, Business and Finance Vol. 1, No. 9, 262 - 274 
syariah compliance oleh Syafei (2013) ${ }^{12}$ menunjukan tidak adanya pengaruh penerapan good corporate governance syariah terhadap kemampulabaan perusahaan. Hasil penelitian terkait shariah compliance dan IPO di Arab Saudi yang dilakukan Alqahtani dan Boulanuoar (2017) menunjukan adanya pengaruh signifikan sharia compliance terhadap permintaan saham IPO.

Pentingnya penerapan corporate governance dan tidak konsistennya hasil beberapa penelitian sebelumnya terkait hubungan corporate governance dengan nilai perusahaan, serta masih sangat terbatasnya penelitian terkait syariah compliance dan pengaruhnya terhadap nilai perusahaaan menjadi latar belakang dilakukannya penelitian ini, untuk menganalisa hubungan antara corporate governance dan pemenuhan prinsip syariah dengan nilai perusahaan pada saat melakukan penawaran saham perdana kepada publik di Bursa Efek Indonesia. berikut:

Hipotesis penelitian yang akan diuji dalam penelitian ini adalah sebagai $\mathrm{H}_{1}$ : Kualitas Corporate Governance mempengaruhi nilai perusahaan saat melakukan Initial Public Offering

Salah satu tujuan penerapan corporate governance adalah mengoptimalkan nilai perusahaan. Perusahaan yang menerapkan good corporate governance dengan baik lebih dipercaya oleh investor sedangkan perusahaan yang mempunyai reputasi kurang baik dalam hal corporate governance akan dijauhi investor (Windah dan Andono, 2013), kepercayaan dari investor tentunya akan meningkatkan nilai perusahaan sebagaimana penelitian Hartzel, Kallberg dan Liu (2008) yang menemukan bahwa perusahaan dengan corporate governance yang kuat mendapat valuasi yang lebih tinggi pada saat melakukan Initial Public Offering.

$\mathrm{H}_{2}$ : Pemenuhan ketentuan syariah mempengaruhi nilai perusahaan saat melakukan Initial Public Offering

Perusahaan yang shariah compliant secara umum dianggap sebagai entitas bisnis yang bebas dari unsur-unsur tidak etis, utamanya terkait integritas dan akuntabilitas (Sulong, Embi dan Ariffin, 2017) ${ }^{13}$, sehingga diharapkan memberikan nilai positif terhadap perusahaan tersebut.

12 Syafei A, Wirman. 2013. Analisis Pengaruh Penerapan Good Governance Bisnis Syariah (GGBS) Terhadap Kemampulabaan (Studi Perusahaan Yang Terdaftar di JII 2011). Jurnal Al-Azhar Indonesia Seri Pranata Sosial Vol. 2 No.2

${ }^{13}$ Sulong, Z., Embi, N. A. C., \& Ariffin, M. R. (2017). Performance of Initial Public Offerings: Does Shariah Compliance Extensiveness Make A Difference? International Journal of Accounting, Finance and Business (IJAFB), 2(6), 190- 205 


\section{METODE PENELITIAN}

Jenis data yang digunakan dalam penelitian ini adalah data sekunder, yaitu data yang diambil dari catatan atau sumber lain yang telah ada sebelumnya. Populasi dalam penelitian ini adalah perusahaan yang melakukan IPO di Bursa Efek Indonesia. Dari populasi tersebut dipilih sampel penelitian dengan menggunakan teknik purposive sampling yaitu prosedur pengambilan data berdasarkan kriteria tertentu. Kriteria yang digunakan dalam penelitian ini membatasi perusahaan yang dijadikan obyek penelitian adalah perusahaan yang memenuhi kriteria berikut:

- Melakukan IPO di Bursa Efek Indonesia dalam periode pengamatan 4 tahun dari tahun 2013 sampai dengan 2016. Pemilihan periode pengamatan 4 tahun terakhir ini dengan pertimbangan akan mampu menggambarkan implementasi tata kelola terkini, sehingga dapat juga dianalisis secara teoritis perkembangan tata kelola perusahaan publik dari masa ke masa.

- Prospektus perusahaan tersedia dan dapat diakses oleh publik melalui database Bursa Efek Indonesia, The Institute of Capital Market Indonesia atau sumber lainnya.

Selama periode pengamatan tersebut terdapat 83 perusahaan yang melakukan penawaran saham perdana di Bursa Efek Indonesia, dari 83 perusahaan tersebut hanya 56 perusahaan yang propektusnya tersedia lengkap dan dapat diakses publik sehingga memenuhi kriteria untuk dijadikan obyek penelitian. Data diperoleh dari Indonesian Capital Market Electronic Library (ICaMEL), Bursa Efek Indonesia (BEI) dan The Institute of Capital Market Indonesia.

Dalam penelitian ini corporate governance direpresentasikan dengan nilai indeks CG yang dikembangkan dengan menggunakan indikator corporate governance yang berpedoman kepada ketentuan-ketentuan terkait corporate governance untuk perusahaan publik yang ditetapkan oleh BAPEPAM-LK/OJK dan BEI yang disajikan dalam Prospektus perusahaan. Terdapat 8 indikator utama corporate governance dan 1 indikator syariah compliance yang kemudian dikuantitatifkan untuk menyusun suatu indeks yang menunjukan kualitas penerapan corporate governance oleh perusahaan yang melakukan IPO, dengan bobot nilai sebagaimana ditunjukan dalam tabel 1.

Berdasarkan bobot nilai tersebut skor maksimal yang dapat diperoleh adalah 17, semakin tinggi skor indeks ini menunjukkan kualitas CG yang semakin baik. Demikian pula sebaliknya, skor yang rendah mengindikasikan kualitas penerapan CG yang kurang baik. Untuk syariah compliance akan bernilai 1 jika perusahaan memenuhi kriteria syariah yang ditetapkan. 
Pengukuran nilai indeks dilakukan berdasarkan ketersedian informasi terkait indikator corporate governance didalam prospektus perusahaan yang melakukan IPO.

Tabel 1. Kriteria Bobot CG dan Syariah Compliance Indeks

\begin{tabular}{|c|c|c|c|}
\hline No. & $\begin{array}{c}\text { Indikator Corporate } \\
\text { Governance }\end{array}$ & $\begin{array}{l}\text { Nilai / } \\
\text { Bobot }\end{array}$ & Kriteria Bobot \\
\hline \multirow[t]{7}{*}{1} & $\begin{array}{l}\text { Struktur Dewan } \\
\text { Komisaris \& Direksi }\end{array}$ & & \\
\hline & $\begin{array}{l}\text { Nama Anggota Dewan } \\
\text { Komisaris }\end{array}$ & $(0,1)$ & $\begin{array}{l}\text { 0: informasi tidak tersedia; } \\
\text { 1: informasi tersedia }\end{array}$ \\
\hline & $\begin{array}{l}\text { Proporsi Komisaris } \\
\text { Independen }\end{array}$ & $(0,1,2)$ & $\begin{array}{l}\text { 0: Proporsi Komisaris } \\
\text { Independen }<30 \%, 1: 30 \%- \\
50 \%, 2:>50 \%\end{array}$ \\
\hline & $\begin{array}{l}\text { Tugas dan Fungsi Dewan } \\
\text { Komisaris }\end{array}$ & $(0,1)$ & $\begin{array}{l}0 \text { : informasi tidak tersedia; } \\
1: \text { informasi tersedia }\end{array}$ \\
\hline & Nama Anggota Direksi & $(0,1)$ & $\begin{array}{l}0 \text { : informasi tidak tersedia; } \\
\text { 1: informasi tersedia }\end{array}$ \\
\hline & Direktur Indenpenden & $(0,1,2)$ & $\begin{array}{l}\text { 0: tidak mempunyai direktur } \\
\text { independen, } 1: \text { mempunyai } 1 \\
\text { direktur independen, } \\
\text { 2: mempunyai direktur } \\
\text { independen }>1\end{array}$ \\
\hline & Tugas dan Fungsi Direksi & $(0,1)$ & $\begin{array}{l}0 \text { : informasi tidak tersedia; } \\
\text { 1: informasi tersedia }\end{array}$ \\
\hline \multirow[t]{3}{*}{2} & Komite Audit & & \\
\hline & $\begin{array}{l}\text { Nama Anggota Komite } \\
\text { Audit }\end{array}$ & $(0,1)$ & $\begin{array}{l}0 \text { : informasi tidak tersedia; } \\
\text { 1: informasi tersedia }\end{array}$ \\
\hline & $\begin{array}{l}\text { Tugas dan Fungsi } \\
\text { Komite Audit }\end{array}$ & $(0,1)$ & $\begin{array}{l}\text { 0: informasi tidak tersedia; } \\
\text { 1: informasi tersedia }\end{array}$ \\
\hline \multirow[t]{3}{*}{3} & $\begin{array}{l}\text { Komite Nominasi dan } \\
\text { Remunerasi }\end{array}$ & & \\
\hline & $\begin{array}{l}\text { Nama Anggota Komite } \\
\text { Nominasi dan } \\
\text { Remunerasi }\end{array}$ & $(0,1)$ & $\begin{array}{l}0 \text { : informasi tidak tersedia; } \\
1 \text { : informasi tersedia }\end{array}$ \\
\hline & $\begin{array}{l}\text { Tugas dan Fungsi } \\
\text { Komite Nomiasi dan }\end{array}$ & $(0,1)$ & $\begin{array}{l}0 \text { : informasi tidak tersedia; } \\
\text { 1: informasi tersedia }\end{array}$ \\
\hline
\end{tabular}




\begin{tabular}{|c|c|c|c|}
\hline & \multicolumn{3}{|l|}{ Remunerasi } \\
\hline 4 & Internal Audit & $(0,1)$ & $\begin{array}{l}\text { 0: informasi tidak tersedia; } \\
\text { 1: informasi tersedia }\end{array}$ \\
\hline 5 & Kantor Akuntan Publik & $(0,1)$ & $\begin{array}{l}\text { 0: KAP non Big Four; } \\
\text { 1: KAP Big Four }\end{array}$ \\
\hline 6 & $\begin{array}{l}\text { Corporate Social } \\
\text { Responsibility }\end{array}$ & $(0,1)$ & $\begin{array}{l}\text { 0: informasi tidak tersedia; } \\
\text { 1: informasi tersedia }\end{array}$ \\
\hline 7 & $\begin{array}{l}\text { Pemegang Saham } \\
\text { Mayoritas }\end{array}$ & $(0,1)$ & $\begin{array}{l}\text { 0: informasi tidak tersedia; } \\
\text { 1: informasi tersedia }\end{array}$ \\
\hline 8 & Transaksi afiliasi & $(0,1)$ & $\begin{array}{l}\text { 0: informasi tidak tersedia; } \\
\text { 1: informasi tersedia }\end{array}$ \\
\hline & Total Nilai & 17 & \\
\hline 9 & Shariah Compliance & $(0,1)$ & $\begin{array}{l}\text { 0: jika salah satu kriteria tidak } \\
\text { terpenuhi, 1: jika seluruh kriteria } \\
\text { terpenuhi }\end{array}$ \\
\hline & Kegiatan Usaha & & $\begin{array}{l}\text { Jenis Usaha tidak termasuk } \\
\text { dalam usaha yang dilarang dalam } \\
\text { prinsip syariah }\end{array}$ \\
\hline & $\begin{array}{l}\text { Utang berbasis bunga } \\
\text { dibanding total aset } \\
<45 \%\end{array}$ & & \\
\hline & $\begin{array}{l}\text { Pendapatan bunga dan } \\
\text { sumber tidak halal } \\
\text { lainnya dibanding total } \\
\text { revenue }<10 \%\end{array}$ & & \\
\hline
\end{tabular}

\section{Variabel Independen}

Penelitian ini menggunakan dua variable independen, yaitu Corporate Governance (CG) dan Sharia Compliance (SC). Corporate governance didefinisikan sebagai pola hubungan, sistem serta proses yang digunakan organ perusahaan guna memberi nilai tambah kepada pemegang saham secara berkesinambungan dalam jangka panjang, dengan tetap memperhatikan kepentingan stakeholder lainnya berlandaskan peraturan perundangan dan norma yang berlaku (KNKG, 2006). Dalam penelitian ini kualitas CG diukur menggunakan indeks yang dikembangkan dengan berpedoman kepada peraturan-peraturan terkait CG yang berlaku bagi perusahaan yang akan melakukan IPO. 
Pengembangan corporate governance indeks sebelumnya pernah dilakukan oleh Gomper, Ishii dan Metric (2003), Bhagat dan Bolton (2008) ${ }^{14}$ dan penelitian Amman, Oesch dan Schmid (2009), Bhalla, Bathia dan Kaushal (2012) dalam penelitiannya terkait Corporate Governance and IPO Underpricing juga menggunakan CGI sebagai variable independen. CG indeks juga dikembangkan oleh Maliah, Norakma dan Noraini (2011) ${ }^{15}$ dalam penelitiannya yang berjudul Developing a Corporate Governance Disclosure Index for Islamic Financial Institutions, dan penelitian yang dilakukan Syafei tentang Analisis Pengaruh Penerapan Good Corporate Governance Syariah terhadap kemampulabaan (2013).

Nilai Indeks ini diharapkan mampu mencerminkan kualitas penerapan Corporate Governance secara lebih komprehensif pada perusahaan yang melakukan IPO. Semakin tinggi nilai indeks menunjukkan semakin tinggi kualitas CG. Indeks ini menggunakan 8 indikator utama yang meliputi Struktur Dewan Komisaris dan Direksi, Komite Audit, Komite Nominasi dan Remunerasi, Internal Audit, Kantor Akuntan Publik, Corporate Social Responsibility, Pemegang saham mayoritas, Transaksi afiliasi. Pengukuran nilai indeks dilakukan berdasarkan ketersedian informasi terkait indikator corporate governance diatas didalam prospektus perusahaan yang melakukan IPO.

Variabel Sharia Compliance (SC) dalam penelitian ini didefinisikan sebagai pemenuhan prinsip-prinsip syariah di pasar modal sesuai peraturan BapepamLK No IX.A.13 tentang Penerbitan Efek Syariah. Indikator SC menggunakan tiga kriteria yang merujuk pada peraturan BAPEPAM-LK No. II.K.1 tentang kriteria dan penerbitan daftar efek syariah, dimana kriteria tersebut meliputi Jenis Kegiatan Usaha Halal tidak bertentangan dengan prinsip-prinisp syariah di pasar modal sebagaimana diatur dalam peraturan Bapepam-LK No. IX.A.13, Rasio Utang berbasis bunga dibanding dengan total asset $<45 \%$, dan rasio pendapatan berbasis bunga dan tidak halal lainya dibanding total pendapatan $($ revenue $)<10 \%$.

Perusahaan yang memenuhi ketiga kriteria di atas diklasifikasikan kedalam perusahaan yang syariah compliance. Sebaliknya jika salah satu dari ketiga indikator tidak terpenuhi maka perusahaan tersebut diklasifikasikan sebagai non-sharia compliance. Indikator SC ini juga telah digunakan oleh OJK dalam menyeleksi saham-saham yang masuk dalam Daftar Efek Syariah.

${ }^{14}$ Bhagat Sanjay and Bolton Brian. 2008. Corporate Governance and Firm Performamce. Journal of Corporate Finance 14, 257-273

${ }^{15}$ Majid Norakma A, Sulaeman Maliah, Ariffin Noraini M. 2011. Developing a Corporate Governance Disclosure Index for Islamic Financial Institutions, $8^{\text {th }}$ International Conference on Islamic Economics and Finance. 
Untuk memperkuat model, maka penelitian ini melengkapi dengan tiga variabel kontrol yang secara konsisten telah banyak digunakan dalam penelitianpenelitian sebelumnya, yaitu:

- Variabel AGE yang mewakili umur perusahaan, diukur dari mulai perusahaan berdiri sampai dengan dilakukannya IPO. Perusahaan yang telah lama berdiri membuktikan kemampuannya dalam bersaing dalam bisnis dan relatif lebih rendah resikonya, sementara perusahaan yang masih baru lebih beresiko (Chahine, Filatotchev, 20116).

- Variabel PROFIT, kinerja profitabilitas telah banyak digunakan sebagai salah satu variable yang berpengaruh terhadap nilai IPO dan merupakan informasi yang penting bagi investor, sebagaimana dalam penelitian Brau dan Fawcet $(2006)^{17}$ dan Ficici, Aybar (2012)..$^{18}$

- Variabel SIZE yang mewakili ukuran perusahaan, perusahaan yang bersakala besar relatif lebih dikenal masyarakat sehingga informasi lebih banyak tersedia yang mana informasi tersebut dapat memperngaruhi persepsi investor. Variable ini digunakan dalam penelitian Gomper, Ishii dan Metrick (2003), Chahine, Filatotchev (2011) dan Ficici, Aybar (2012).

\section{Variabel Dependen}

Variable dependen dalam penelitian ini adalah Nilai Perusahaan IPO yang merefleksikan persepsi investor atas potensi nilai perusahaan, dimana persepsi investor merupakan faktor utama yang mempengaruhi penentuan harga saham (Wu dan Willenborg, 2014 ${ }^{19}$ ). Dalam penelitian ini nilai perusahaan merujuk kepada penelitian yang dilakukan Aggarwal (2009) ${ }^{20}$ dan Ozcelik (2014) dimana nilai perusahaan direpresentasikan dengan total nilai harga penawaran perdana per saham (Harga saham IPO) dikalikan dengan post-IPO outstanding shares (jumlah saham yng beredar setelah IPO), nilai inilah yang diestimasi oleh underwriter atau investment bank pada saat tahapan valuasi dalam proses IPO.

\footnotetext{
${ }^{16}$ Chahine Salim, Filatotchev Igor. 2011. The Effect of Corporate Governance and Audit and Non-Audit Fees on IPO Value. The British Accounting Review 43, 155-172.

17 Brau, J. C. and S. Fawcett. 2006. Initial public offerings: An analysis of theory and practice. The Journal of Finance 61, 399-436.

18 Ficici A, Aybar C. B. 2012. Corporate Governance and Firm Value in Emerging Markets an Empirical Analysis of ADR Issuing Emerging Market Firm. Emerging Market Journal Volume 2.

19 Willenborg Michael and Wu Biyu (2014), Issuer Operating Performance and IPO Pricing Formation, University of Connecticut.

20 Aggarwal, R. 2009. The Impact of Fundamentals on IPO Valuation. Financial Management, 253-284.
} 


\section{Nilai Perusahaan IPO = Harga Saham IPO * post-IPO Outstanding} Shares

Untuk mengatasi masalah normalitas dan heterokedastisitas, nilai perusahaan menggunakan transformasi logaritma natural (Ozcelik, 2014).

\section{Model Penelitian}

Model penelitian yang digunakan dalam penelitian ini menggunakan regresi berganda yang digunakan dalam penelitian Gomper, Ishii dan Metrick (2003), Bhagat dan Bolton (2008), dan beberapa penelitian sejenis lainnya, model regresi yang digunakan dalam penelitian ini adalah sebagai berikut:

Nilai Perusahaan IPO $=\beta 0+\beta 1 \mathrm{CG}+\beta 2 \mathrm{SC}+\beta 3 \mathrm{AGE}+\beta 4 \mathrm{PRF}+\beta 5 \mathrm{SIZE}+\varepsilon$ dimana:

Nilai Perusahaan IPO : diukur dengan logaritma natural Total nilai perusahaan (harga saham IPO * Post-IPO outstanding shares)

CG : Nilai indeks corporate governance

SC : Nilai indeks syariah compliance

AGE : Umur perusahaan sejak berdiri sampai dengan IPO

PRF : Profitability Perusahaan, diukur dengan Laba usaha/Pendapatan usaha

SIZE : Ukuran Perusahaan, diukur dengan logaritma natural total pendapatan Usaha

\section{HASIL PENELITIAN DAN PEMBAHASAN}

Deskripsi statistik sampel penelitian disajikan dalam tabel 2, mencakup variabel penelitian, nilai minimum dan maksimum, standar deviasi, median dan mean dari variable penelitian. Jumlah sampel penelitian adalah 56 perusahaan, nilai minimum indeks corporate governance sebesar 10 dan maksimum 16 yang dicapai oleh dua perusahaan yang melakukan IPO di tahun 2013 dan 2016, dengan rata-rata 12.18 dan standar deviasi 1.47. Syariah indeks bernilai 0 dan 1 dengan mean dan standar deviasi masing-masing 0.50 dan 0.46. Median dari syariah indeks bernilai 0 yang artinya sebagian besar sampel penelitian tidak memenuhi kriteria syariah compliance. 
180 |Al-Falah: Journal of Islamic Economics, Vol.3, No.2, 2018

Tabel 2. Deskripsi Statistik

\begin{tabular}{|l|c|c|c|c|c|}
\hline \multicolumn{1}{|c|}{ Variabel } & Standar Deviasi & Median & Minimum & Maximum & Mean \\
\hline CG Indeks & 1.47 & 12.00 & 10.00 & 16.00 & 12.18 \\
\hline Syariah Indeks & 0.50 & 0.00 & 0.00 & 1.00 & 0.46 \\
\hline Profit & 0.19 & 0.17 & -0.16 & 0.83 & 0.21 \\
\hline Size & $1,792,472,647,737$ & $387,852,036,140$ & $23,545,000,000$ & $10,776,919,000,000$ & $1,085,194,053,793$ \\
\hline Age & 12.11 & 18.00 & 2.00 & 57.00 & 19.38 \\
\hline Nilai IPO & $5,194,248,107,791$ & $1,241,160,000,000$ & $105,000,000,000$ & $24,736,251,200,000$ & $3,180,084,607,563$ \\
\hline
\end{tabular}

Variabel profit mempunyai nilai minimum -0.16 dan maksimum 0.83 dengan standar deviasi dan median 0.19 dan 0.17 , nilai minimum dan maksimum variabel size masing-masing 23.545.000.000 dan 10.776.919.000.000 dengan standar deviasi 1.792.472.647.737 dan nilai mean 1.085.194.053.793. Variabel terakhir, umur perusahaan mempunyai nilai minmum 2 dan maksimum 57 dengan standar deviasi 12.11 dan mean 19.38. Untuk variable dependen yaitu nilai perusahaan IPO, nilai minimum dan maksimum masing-masing 105.000.000.000 dan 24.736.251.200.000, standar deviasi 5.194.248.107.791 dengan nilai median dan mean 1.241.160.000.000 dan 3.180.084.607.563.

\section{Uji Asumsi klasik}

Uji asumsi klasik diperlukan untuk memastikan model regresi yang digunakan memenuhi beberapa asumsi statistik yang dipersyaratkan sehingga valid untuk digunakan sebagai estimator linear dan tidak bias atau dikenal dengan BLUE (Best Linear Unbiased Estimator), untuk itu sebelum melakukan analisi regresi perlu dilakukan uji asumsi klasik terlebih dahulu.

\section{Uji Normalitas}

Uji normalitas dilakukan untuk mengetahui apakah model regresi mempunyai distribusi data normal atau mendekati normal. Untuk menghindari terjadinya bias, nilai residual model regresi yang digunakan harus terdistribusi normal. Dalam penelitian ini pengujian dilakukan dengan metoda analisis grafik histogram untuk melihat secara visual pola distribusi nilai residual dari model. Hasil uji normalitas dengan metode histogram ditunjukan gambar dibawah ini: 


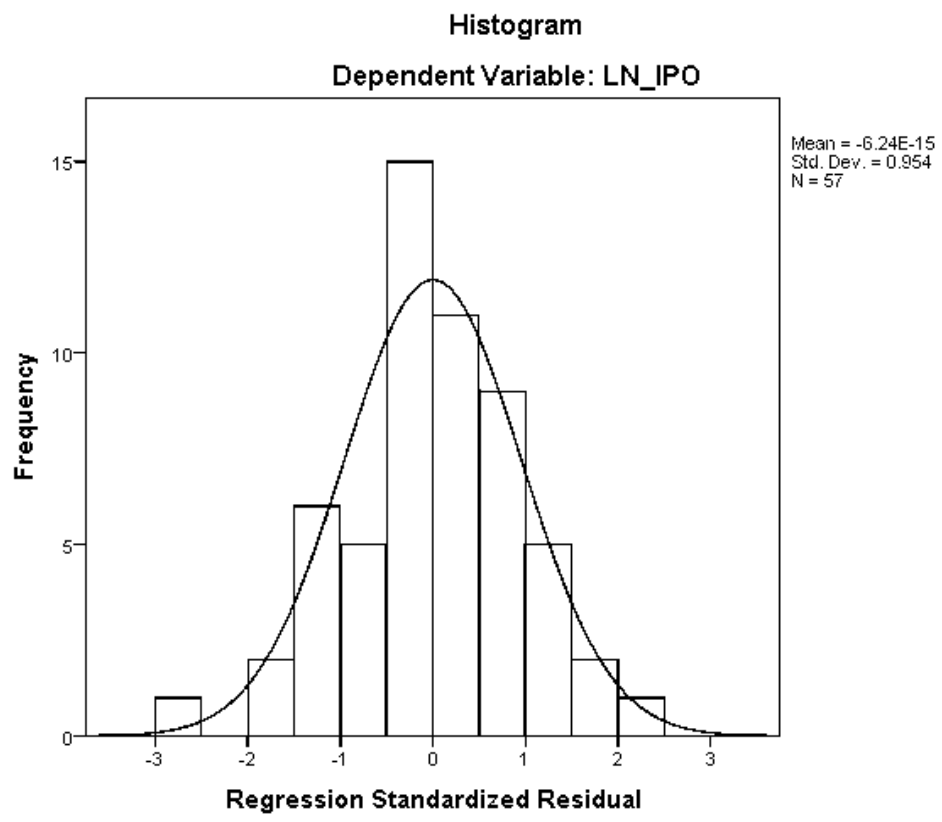

Gambar 1. Histogram

Dari histogram diatas dapat dilihat bahwa nilai residual dari model regresi mengikuti pola distribusi normal berbentuk lonceng sehingga dapat disimpulkan model regresi telah memenuhi asumsi normalitas.

\section{Uji Multikolinearitas}

Uji asumsi yang kedua adalah uji multikolineraritas, model regresi yang baik seharusnya tidak ada korelasi yang tinggi diantara variabel independen. Uji multikolinearitas ini bertujuan untuk menguji apakah di dalam model regresi ditemukan adanya korelasi yang tinggi antar variabel independen yang ada. Dalam penelitian ini, cara yang digunakan untuk melihat ada tidaknya multikolinieritas yaitu dengan melihat nilai Tolerance dan Variance Inflation Factor (VIF). Kedua ukuran ini menunjukan setiap variabel independen manakah yang dijelaskan oleh variabel independen lainnya. Tolerance mengukur variabilitas variabel independen yang terpilih yang tidak dapat dijelaskan oleh variabel independen lainnya. Nilai batas yang umum digunakan untuk menunjukkan adanya multikolinieritas adalah nilai Tolerance $<0,10$ atau sama dengan nilai VIF $>10$, dari hasil pengolahan data didapat data sebagai berikut: 
182 |Al-Falah: Journal of Islamic Economics, Vol.3, No.2, 2018

\begin{tabular}{|c|c|c|c|}
\hline Variable & $\begin{array}{l}\text { Coefficient } \\
\text { Variance }\end{array}$ & $\begin{array}{c}\text { Uncentered } \\
\text { VIF }\end{array}$ & $\begin{array}{c}\text { Centered } \\
\text { VIF }\end{array}$ \\
\hline CG_INDEKS & 0.006282 & 77.77935 & 1.091480 \\
\hline SYARIAH_INDEKS & 0.058182 & 2.223390 & 1.191102 \\
\hline PRÖFIT & 0.390597 & 2.529450 & 1.111205 \\
\hline LN_SIZE & 0.006186 & 366.3061 & 1.039549 \\
\hline$\overline{\mathrm{AGE}}$ & $8.76 \mathrm{E}-05$ & 3.744306 & 1.038206 \\
\hline $\mathrm{C}$ & 5.380894 & 442.8898 & NA \\
\hline
\end{tabular}

Dari hasil pengolahan data diatas didapat nilai VIF untuk setiap variable $<10$ sehingga tidak ada gejala multikolinearitas dan model regresi memenuhi asumsi non-multikolinearitas.

\section{Uji Heterokedastisitas}

Heterokedastisitas terjadi jika ada ketidaksamaan varian dari residual satu pengamatan ke pengamatan yang lain, untuk mengujinya digunakan metode scatter plot dengan memplot nilai prediksi dan nilai residualnya. Kriteria pengambilan keputusan adalah jika plot-plot tersebut membentuk pola-pola tertentu yang teratur maka terjadi gejala heterokedastisitas.

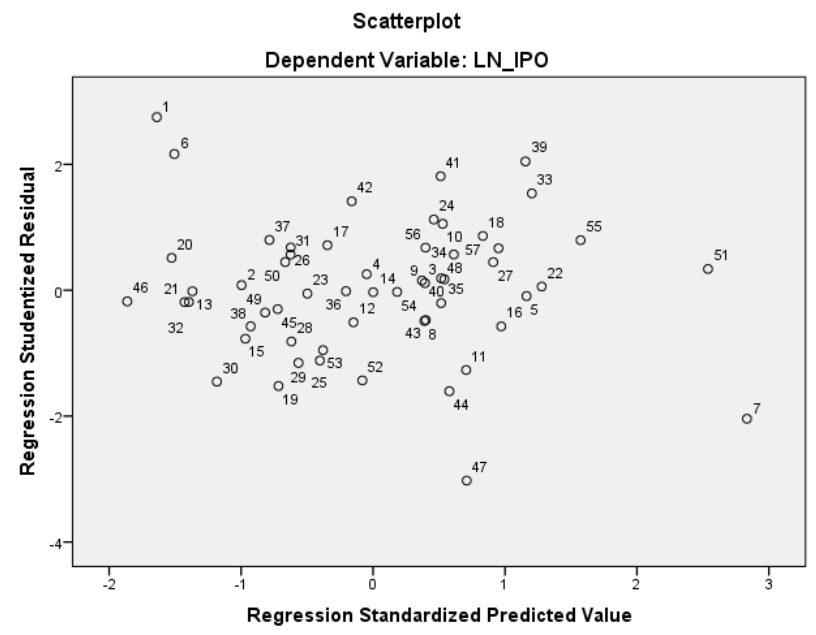

Gambar 2. Scatter Plot Uji Heterokedastisitas

Dari scatter plot diatas terlihat tidak ada pola tertentu didalamnya sehingga model memenuhi asumsi homoskedastisitas. Cara lain uji heterokedastisitas dengan uji statistic Glejser, didapat hasil sebagai berikut: 
Heteroskedasticity Test: Glejser

\begin{tabular}{llll}
\hline \hline F-statistic & 0.735136 & Prob. F(5,50) & 0.6006 \\
Obs*R-squared & 3.834846 & Prob. Chi-Square(5) & 0.5734 \\
Scaled explained SS & 4.175408 & Prob. Chi-Square(5) & 0.5244 \\
\hline \hline
\end{tabular}

Dari hasil pengolahan data diatas diperoleh nilai $\mathrm{p}$-value Obs*R-squared adalah 0.5734 yang mana $>0.05$, maka dapat disimpulkan bahwa dalam model regresi tidak ditemukan adanya gejala heterokedastisitas.

Dari uji asumsi klasik yang telah dilakukan maka dapat disimpulkan bahwa model regresi yang dipakai telah memenuhi asumsi-asumsi statistik tersebut sehingga valid untuk digunakan sebagai estimator.

\section{Uji Model}

Pengujian model dilakukan menggunakan metode regresi berganda dengan level signifikansi $5 \%$ atau $\alpha=0.05$, model regresi berganda yang digunakan adalah sebagai berikut:

Nilai Perusahaan $=\beta 0+\beta 1 C G+\beta 2 S C+\beta 3 A G E+\beta 4 P R F+\beta 5 S I Z E+\varepsilon$

Dari hasil pengolahan model regresi diatas didapatkan data sebagai berikut:

Tabel 3. Model Summary

Dependent Variable: LN_NILAI_IPO

Method: Least Squares

Sample: 156

Included observations: 56

\begin{tabular}{crrrr}
\hline \hline Variable & Coefficient & Std. Error & t-Statistic & Prob. \\
\hline \hline CG_INDEKS & 0.222304 & 0.079259 & 2.804790 & 0.0072 \\
SYARIAH_INDEKS & -0.073255 & 0.241210 & -0.303697 & 0.7626 \\
PROFIT & 1.356758 & 0.624977 & 2.170891 & 0.0347 \\
LN_SIZE & 0.738083 & 0.078653 & 9.384037 & 0.0000 \\
AGE & -0.009836 & 0.009359 & -1.051012 & 0.2983 \\
C & 5.341736 & 2.319675 & 2.302795 & 0.0255 \\
\hline \hline R-squared & 0.666993 & Mean dependent var & 27.87798 \\
Adjusted R-squared & 0.633692 & S.D. dependent var & 1.362857 \\
S.E. of regression & 0.824847 & Akaike info criterion & 2.553719 \\
Sum squared resid & 34.01863 & Schwarz criterion & 2.770721 \\
Log likelihood & -65.50414 & Hannan-Quinn criter. & 2.637851 \\
F-statistic & 20.02938 & Durbin-Watson stat & 2.182307 \\
Prob(F-statistic) & 0.000000 & & & \\
\hline \hline
\end{tabular}




\section{Adjusted R-Squared}

Dari data tabel 3 didapatkan nilai Adjusted R-Squared sebesar 0.633. Nilai tersebut menunjukan bahwa model regresi yang digunakan dalam penelitian ini cukup kuat dalam menjelaskan variability nilai perusahaan IPO yang mana mencapai 63\%, sisanya 43\% dijelaskan faktor lain yang tidak masuk dalam model penelitian. Hal ini tentunya wajar karena selain dari variabelvariabel yang digunakan dalam penelitian ini, beberapa faktor lain juga mempengaruhi nilai perusahaan IPO misalnya informasi keuangan, struktur kepemilikan dan kondisi pasar modal (Ozcelik, 2014).

\section{Uji Simultan (Uji F)}

Uji F dilakukan untuk melihat pengaruh semua variabel independen dalam model regresi secara simultan terhadap variabel dependen. Hipotesis yang digunakan adalah sebagai berikut:

- $\mathrm{H}_{0}$ : Tidak terdapat pengaruh signifikan

- $\mathrm{H}_{1}$ : Terdapat pengaruh signifikan

Dasar pengambilan keputusan dalam pengujian ini adalah sebagai berikut:

- Jika, signifikansi nilai $\mathrm{F}>\alpha$, maka $\mathrm{H}_{0}$ diterima

- Jika, signifikansi nilai $\mathrm{F}<\alpha$, maka $\mathrm{H}_{1}$ diterima

Dari tabel 3 didapat nilai F-statistik adalah 20.03 dengan nilai signifikasi 0.00 yang mana $<0.05$ sehingga $\mathrm{H}_{1}$ diterima dan dapat disimpulkan variablevariabel independen dalam model regresi yaitu CG Indeks, Syariah Indeks, Profit, Size dan Age secara simultan berpengaruh signifikan terhadap nilai perusahaan IPO sebagai variabel dependen. Berdasarkan hasil pengolahan regresi berganda pada tabel 4.6 diperoleh persamaan regresi berganda sebagai berikut:

Nilai Perusahaan IPO $=5.342+0.222$ CG Indeks -0.073 Syariah Indeks +

$$
\text { 1.357 Profit }+0.738 \text { Size }-0.009 \text { Age }+\varepsilon
$$

\section{Uji Parsial (Uji -t)}

Dari tabel 3 di atas dapat dilihat bahwa variabel CG indeks yang mewakili kualitas corporate governance mempunyai koefisien positif 0.222 dengan nilai t-statistic 2.766 dan nilai signifikansi 0.0079 yang mana $<0.05$, oleh karenanya dapat dikatakan bahwa CG Indeks berpengaruh positif dan signifikan terhadap nilai perusahaan IPO, sehingga dapat dinyatakan bahwa kualitas Corporate Governance mempengaruhi nilai perusahaan saat melakukan Initial Public Offering. 
Pemenuhan ketentuan syariah dalam model regresi ini direpresentasikan dengan variable syariah indeks, tabel 3 menunjukan bahwa variable syariah indeks mempunyai koefisien negatif -0.073 dengan nilai signifikansi 0.762 yang mana $>\alpha$ yang digunakan dalam penelitian ini yaitu 0.05 , oleh karenanya dapat dikatakan variable syariah indeks tidak mempunyai pengaruh yang signifikan terhadap nilai perusahaan IPO, sehingga penelitian ini menunjukan bahwa pemenuhan ketentuan syariah tidak mempengaruhi nilai perusahaan saat melakukan Initial Public Offering.

Selain CG Indeks, variabel profit juga berpengaruh positif dan signifikan dengan koefisien 1.357 dan nilai signifikansi 0.0347 yang mana lebih kecil dari $\alpha$ $=0.05$. Variable ketiga yang berpengaruh positif dan signifikan adalah variable size dengan koefisien 0.678 dan nilai signifikansi 0.00 , sehingga dapat disimpulkan bahwa variable profit dan size perusahaan mempengaruhi nilai perusahaan IPO secara positif dan signifikan.

Variabel terakhir yaitu umur perusahaaan, mempunyai koefisien negatif -0.009 dan nilai signifikansi 0.298 yang mana lebih besar dari 0.05 , sehingga dalam model regresi ini umur perusahaan tidak cukup signifikan mempengaruhi nilai IPO.

\section{PEMBAHASAN}

Hasil pengujian hipotesis 1 membuktikan adanya pengaruh yang signifikan dari kualitas corporate goverance terhadap nilai perusahaan IPO. Hasil ini sejalan dengan penelitian sebelumnya yang dilakukan Gomper, Ishii dan Metric (2003) yang menggunakan indeks yang dikembangkan berdasarkan shareholder rights sebagai proxy corporate governance dan Cheung et all (2014) yang mengembangkan indeks corporate governance menggunakan prinsip-prinsip corporate governance dari OECD, dimana kedua penelitian tersebut menemukan adanya pengaruh positif corporate governance terhadap nilai perusahaan. Hasil ini juga mendukung penelitian Hartzell, Kallberg and Liu (2008) dan Chahine Filatotchev (2011) mengindikasikan bahwa perusahaan dengan corporate governance yang lebih kuat mendapatkan nilai IPO yang lebih tinggi.

Salah satu faktor yang dapat menyebabkan rendahnya nilai perusahaan saat IPO adalah asimetri informasi antara perusahaan dan investor, dimana investor mempunyai informasi yang terbatas tentang perusahaan sehingga menyebabkan permintaan diskon atas harga saham (Spence, 1973) ${ }^{21}$. Tranparansi yang merupakan salah satu prinsip corporate governance mengandung unsur pengungkapan dan penyediaan informasi yang memadai dan mudah diakses oleh

${ }^{21}$ Spence A. 1973. Job Market Signaling. Quarterly Journal of Economics, 87, 355-379. 
pemangku kepentingan diharapkan dapat mengurangi asimetri informasi tersebut, salah satu caranya adalah melalui informasi yang disampaikan dalam prospektus sehingga dapat memberikan informasi yang cukup memadai bagi investor untuk digunakan sebagai pertimbangan dalam pengambilan keputusan investasi.

Penelitian ini juga memasukan independensi dewan komisaris sebagai salah satu komponen indeks corporate governance. Dewan komisaris menjalankan fungsi pengawasan dalam perusahaan yang berperan penting dalam corporate governance, hal ini tercermin dalam penelitian Lastanti (2004) ${ }^{22}$ yang menemukan bahwa independensi dewan komisaris berpengaruh positif signifikan terhadap nilai perusahaan. Adanya pengaruh positif tersebut disebabkan oleh mekanisme kontrol yang kuat dari komisaris independen terhadap manajemen, dimana mekanisme kontrol tersebut merupakan peran vital bagi terciptanya good corporate governance.

Hasil penelitian menunjukan bahwa pemenuhan ketentuan syariah atau syariah compliance tidak terbukti mempengaruhi nilai perusahaan pada saat melakukan penawaran saham perdana, hal ini dapat dijelaskan karena tidak semua investor memperhatikan kesyariahan suatu produk saham saat membuat keputusan investasi, sebagaimana hasil penelitian ini dimana kinerja keuangan perusahaan masih menjadi faktor pertimbangan utama dalam berinvestasi. Hal ini ditunjukan juga dalam penelitian yang dilakukan Alqahtani dan Boulanuoar (2017) terkait shariah compliance dan IPO di Arab Saudi yang menunjukan bahwa investor institusi cenderung untuk mengutamakan profit dibanding shariah compliance, sementara individual investor lebih mengutamakan pemenuhan ketentuan syariah.

Kriteria efek syariah sendiri yang mengatur terkait jenis usaha halal, pembatasan hutang dan pendapatan non halal dibuat berdasarkan ketentuanketentuan hukum Islam dan ditujukan untuk memberikan pedoman bagi pelaku pasar modal yang ingin kegiatan muamalahnya dipasar modal sesuai dengan syariah Islam, sehingga bagi pelaku pasar modal yang memang tidak menjadikan syariah sebagai pedoman dalam bertransaksi tentunya kriteria syariah ini bukan sesuatu hal yang menjadi pertimbangan dalam membuat keputusan investasi. Berdasarkan data Bursa Efek Indonesia per September 2017 jumlah investor saham syariah (investor yang membuka rekening efek syariah) berjumlah 19.265 investor atau hanya 3,2\% dari total investor di Bursa Efek Indonesia.

${ }^{22}$ Lastanti, Hexana Sri. 2004. Hubungan Struktur Corporate Governance dengan Kinerja Perusahaan dan Reaksi Pasar. Konferensi Nasional Akuntansi: Peran Akuntan dalam Membangun Good Corporate Governance. 


\section{PENUTUP}

Corporate governance merupakan salah satu faktor yang berpengaruh positif terhadap nilai perusahaan yang melakukan IPO, hal ini dibuktikan berdasarkan hasil penelitian dimana variabel CG Indeks berpengaruh positif dan signifikan pada level $\alpha=5 \%$. Hasil penelitian ini mendukung penelitian sebelumnya yang dilakukan Hartzell, Kallberg and Liu (2008) dan Chahine Filatotchev (2011), yang menemukan bahwa perusahaan dengan corporate governance yang lebih baik mendapatkan valuasi yang lebih tinggi pada saat melakukan penawaran saham perdana. Hasil penelitian ini menegaskan kembali pentingnya penerapan corporate governance dalam perusahaan, dimana corporate governance ini terbukti menjadi salah satu faktor positif yang mempengaruhi nilai perusahaan pada saat penawaran saham perdana. Hal ini sesuai dengan salah satu tujuan dari corporate governance yaitu mengoptimalkan nilai perusahaan bagi pemegang saham. Dengan penerapan corporate governance yang baik tentunya investor akan merasa lebih aman untuk berinvestasi di perusahaan tersebut sehingga dengan persepsi yang baik dari investor menjadikan nilai perusahaan tersebut meningkat, oleh karenanya corporate governance harus dipandang sebagi sebuah peluang dan benefit dibandingkan sebagai cost bagi perusahaan.

Pemenuhan ketentuan syariah tidak terbukti mempengaruhi nilai perusahaan saat melakukan penawaran saham perdana, dimana variabel syariah Indeks tidak cukup signifikan pada level $\alpha=5 \%$. Hal ini dapat dijelaskan karena belum semua pelaku pasar modal menaruh perhatian terhadap ketentuan syariah, data dari Bursa Efek Indonesia menunjukan hanya 3,2\% dari total investor di Bursa Efek Indonesia terdaftar sebagai investor yang membuka rekening efek syariah. Peraturan terkait kriteria efek syariah sendiri didasarkan kepada ketentuan dan dalil dari Al Quran, hadist dan fatwa ulama Islam sehinga dapat dipahami jika pelaku pasar modal yang bukan hanya dari umat Islam belum menjadikan pemenuhan ketentuan syariah sebagai faktor yang memperngaruhi nilai perusahaan pada saat melakukan penawaran saham perdana.

Beberapa saran untuk pengembangan penelitian selanjutnya antara lain:

1. Penelitian ini hanya menggunakan periode data 4 tahun dari 2013 sampai dengan 2016 dengan sampel data 56 perusahaan, untuk penelitian selanjutnya disarankan untuk mengunakan periode yang lebih panjang sehingga sampel yang digunakan lebih banyak.

2. Penelitian ini tidak mempertimbangkan kondisi pasar modal pada saat penawaran saham perdana dilakukan, disarankan untuk penelitian selanjutnya memasukan kondisi pasar modal kedalam penelitian. 
3. Pengembangan corporate governance indeks dalam penelitian ini hanya menggunakan informasi dari propektus perusahaan, untuk penlitian selanjutnya diharapkan dapat mengembangkan indeks corporate governance yang lebih komprehensif tdak hanya berdasarkan informasi dalam prospektus, akan lebih baik jika dapat melakukan survey terkait mekanisme corporate governance perusahaan yang dijadikan sampel.

\section{DAFTAR PUSTAKA}

Abdusallam. 2009. Corporate Governance from Islamic Perspective: A Comparative Analysis with OECD Principles. Critical Perspective on Accounting 20, 556-567.

Aggarwal, R. 2009. The Impact of Fundamentals on IPO Valuation. Financial Management, 253-284

Alqahtani F and Boulanouar Z. 2017. Sharia compliance status \& investor demand for IPOs: Evidence from Saudi Arabia. Pacific-Basin Finance Journal Volume 46, Part B, 258-268

Amman Manuel, Oesch David and Schmid Markus. 2009. Corporate Governance and Firm Value: International Evidence, Swis Institute and Banking Finance, University of St Gallen, Working Paper.

Bakar, N. A and Uzaki, K. 2013. Initial Public Offerings (IPOs): An Empirical Study of Initial Public Offerings Underpricing For Shariah-compliant Companies: The Case of Malaysian Market. International Journal of Economics, Business and Finance Vol. 1, No. 9, 262 - 274

Bhalla Lalit, Bhatia Akshay, Kaushal Vijay. 2012. Corporate Governance and IPO Underpricing, Jounal of Commerce and Accounting Research Vol.1 Issue 3

Bhagat Sanjay and Bolton Brian. 2008. Corporate Governance and Firm Performamce. Journal of Corporate Finance 14, 257-273.

Brau, J. C. and S. Fawcett. 2006. Initial public offerings: An analysis of theory and practice. The Journal of Finance 61, 399-436.

Chahine Salim, Filatotchev Igor. 2011. The Effect of Corporate Governance and Audit and Non-Audit Fees on IPO Value. The British Accounting Review 43, 155-172.

Cheung Y.L, Connelly J.T, Estanislao J, Limpaphayom, Lu T, Utama. 2014. Corporate Governance and Firm Valuation in Asian Emerging Markets, Springer-Verlag Berlin Heidelberg. 
Ficici A, Aybar C. B. 2012. Corporate Governance and Firm Value in Emerging Markets an Empirical Analysis of ADR Issuing Emerging Market Firm. Emerging Market Journal Volume 2.

Gompers, P., J. Ishii, and A. Metrick. 2003. Corporate Governance and Equity Prices. Quarterly Journal of Economics, 118, 107-155.

Haat, Rahman, Mahenthiran. 2008. Corporate Governance, Transparency and Performance of Malaysian Companies. Managerial Auditing Journal Volume. 23 No.8, 744-778.

Hasan Zulkifli. 2009. Corporate Governance: Western and Islamic Perspective. International Review for Business Research Paper Vol.5, 277-293.

Hartzell Jay C, Kallberg Jarl G and Liu Crocker H. 2008. The Role of Corporate Governance in Initial Public Offerings: Evidence from Real Estate Investment Trust. The Journal of Law and Economics Vol.51.

Hidayat Arief Wahyu dan Kusumatuti Retno. 2013. Pengaruh Struktur Corporate Governance Terhadap Underpricing (Studi Terhadap Perusahaan Yang Melakukan IPO di Indonesia Periode 2005-2012)

Jensen, M.C. and W.H. Meckling. 1976. Theory of the firm: managerial behavior, agency costs, and ownership structure. Journal of Financial Economics, 3, 305-360.

Jun Lin, Ming Liu. 2009. The Impact of Corporate Governance on Auditor Choice: Evidence from China, Journal of International Accounting, Auditing and Taxation 18, 44-59

Kim, M. and Ritter,J.R. 1999.Valuing IPOs. Journal of Financial Economics, 53, 409-437.

Lastanti, Hexana Sri. 2004. Hubungan Struktur Corporate Governance dengan Kinerja Perusahaan dan Reaksi Pasar. Konferensi Nasional Akuntansi: Peran Akuntan dalam Membangun Good Corporate Governance.

Majid Norakma A, Sulaeman Maliah, Ariffin Noraini M. 2011. Developing a Corporate Governance Disclosure Index for Islamic Financial Institutions, $8^{\text {th }}$ International Conference on Islamic Economics and Finance.

Meouchi Badri El. 2007. The Benefit of Corporate Governance, Lebanese Transparency Association.

Ozcelik Zeynep. 2014. The Impact of Ownership Retention on IPO Firm Value. British Journal of Economics, Finance and Management Sciences Volume 9, 133-148. 
Syafei A, Wirman. 2013. Analisis Pengaruh Penerapan Good Governance Bisnis Syariah (GGBS) Terhadap Kemampulabaan (Studi Perusahaan Yang Terdaftar di JII 2011). Jurnal Al-Azhar Indonesia Seri Pranata Sosial Vol. 2 No.2.

Spence A. 1973. Job Market Signaling. Quarterly Journal of Economics, 87, 355-379.

Sulong, Z., Embi, N. A. C., \& Ariffin, M. R. (2017). Performance of Initial Public Offerings: Does Shariah Compliance Extensiveness Make A Difference? International Journal of Accounting, Finance and Business (IJAFB), 2(6), 190- 205

Willenborg Michael and Wu Biyu (2014), Issuer Operating Performance and IPO Pricing Formation, University of Connecticut.

Windah Gabriela C dan Andono Fidelis A (2013), Pengaruh Penerapan Corporate Governance Terhadap Kinerja Keuangan Perusahaan hasil Survei The Indonesian Institute Perception Governance (IICG) Periode 2008-2011, Jurnal Ilmiah Mahasiswa Universitas Surabaya Vol 2 No.1

Komite Nasional Kebijakan Governance. 2011. Pedoman Umum Corporate Governance Bisnis Syariah. 